\title{
How South Korea has kept the impact of COVID-19 on jobs in check
}

Edition 4, 2020

Associate Professor Kyoung-Hee $\mathrm{Yu}$

DOI: 10.37839/MAR2652-550X4.9

South Korea was one of the earliest countries impacted by COVID-19. Since its peak in late February South Korea's efforts to curb the spread of the epidemic have been widely recognized as being highly successful, through a combination of preemptive and efficient testing of a large population, technology-enabled contact tracing, social distancing and mask wearing. By late April in 2020 when the virus was taking hold in other parts of the world, South Korea was marking single digit daily increases. Despite an outbreak at a church north of Seoul in early September, it has recorded only approximately 24,000 cases in a population of more than 50 million.

\section{South Korea's response has not involved severe restrictions on movement}

A hallmark of South Korea's battle with COVID-19 has been that it has not relied on severe lockdown measures, unlike in other countries such as the United States, national in Western Europe, and Australia. In contrast to border closures in the United States, Australia and other nations, South Korea has never closed its borders with neighboring countries. Further, instead of forced quarantines in governmentmandated facilities, visitors have undergone health checks on arrival and are encouraged to download apps that trace their movements. 
South Korea even held its general election on April 15, the first nation to hold national elections in the midst of the pandemic. It was held with special guidelines relating to social distancing, where officials and volunteers handed out masks and hand sanitiser and oversaw a required two metre distance between voters.

The South Korean response to COVID-19 reflects learning from earlier experiences with epidemics-SARS in 2002-2003, H1N1 in 2009, and the Middle Eastern Respiratory Syndrome (MERS) in 2015. The political ramifications of these disasters for previous governments suffered have also contributed to the current government's responsiveness. In addition to virus control, the sinking of the Sewol ferry in 2014 in which 304 passengers drowned, including 262 high school students on a school excursion, has been a national trauma that called for government accountability over large-scale disasters. The incident served as a pivotal event that propelled protests leading to the impeachment of a sitting president and a change in government.

The current government, headed by President Moon Jae-In, declared a national emergency on $23^{\text {rd }}$ February, ahead of other governments were experiencing the spread of the virus. Perhaps unlike in other countries where responses to the pandemic have been localised, the South Korean response has been to centralise coordination over the public health emergency by the national government in consultation with local governments. The government secured a supply of masks, distributing them through pharmacies. To avoid panic buying, individuals were limited to purchasing three surgical masks per week and no restrictions were placed on the purchase of reuseable fabric masks. The government also invested in biotech companies that developed effective COVID-19 diagnostic kits and over 30 such companies are currently exporting the kits worldwide.

Public trust in government institutions in South Korea was at an all time high at 39 percent in 2019, and higher than in other OECD (the Organisation for Economic Cooperation and Development) members such as the U.S., Japan, Italy and Spain, reflecting the fact that the current government was voted in on a reform ticket after 
corruption charges against the previous president. The South Korean public has come to appreciate the public health benefits of wearing masks through previous exposure to respiratory diseases. According to the data analytics group YouGov, mask usage in Asian countries in July 2020 averaged over 90 percent compared to 73 percent in the US, 36 percent in the UK, 20 percent in Australia (except in the Australian state of Victoria where mask wearing is currently mandatory), and tiny percentages in Northern European countries; South Korea was not covered independently in this study). Importantly, mask wearing in South Korea has not been the source of political controversy unlike in other countries.

\section{The overall impact on employment has been less severe than in other countries}

During March and April, South Korea lost just over a million jobs and an additional 990,000 were furloughed, but over the course of May and June the country recovered about a million jobs. The unemployment rate ranged between 4.2-4.5 percent during March to June; however, youth unemployment rate remained at 10.7 percent even whilst the overall unemployment rate improved in May and June. The OECD has recently forecast a -1 percent economic growth for South Korea in 2020 (revised downward from -0.8 to reflect a second wave of COVID-19), compared to -3.8 percent for the US, -5.4 percent for Germany, and -10.1 percent for the UK. South Korea has undergone two recent economic crises in recent decades, the global financial crisis of 2008 and the Asian financial crisis of 1997, and in each of these it took 14-16 months for jobs to recover. As with many other countries, however, the impact on employment has fallen disproportionately on women and vulnerable workers.

While all industries have been impacted by COVID-19, employment has fallen by the largest proportion in accommodation and food preparation and is showing a slow recovery in this industry even while other industries have gained some lost ground 
since April. Employment in manufacturing has been relatively less impacted by COVID -19, having been declining since before the pandemic and also having benefited from government relief programs. While the sector witnessed a decline in production and demand for exports during March and April, exports in semiconductors, a major export item for South Korea, remained strong.

\section{Female workers have been hit hard}

Demographically, the recession in South Korea prompted by COVID-19 has hit women and younger and older workers hardest. These groups hold jobs in industries that have been impacted most by COVID-19, as well as in non-regular forms of employment with little security. Among OECD countries, South Korea ranked 29 out of 29 in the glass ceiling index-a measure of gender equality at work that includes educational attainment, labour-market attachment, pay, and representation in senior jobs. For every dollar earned by a man, a woman in South Korea earns 67 cents (the OECD average is 87 cents). The employment rate for women in all age groups fell more sharply than that of men during the months impacted by COVID-19. During the second quarter of 2020,250,000 women lost jobs compared to 160,000 men. While the employment ratesfor men in the 30-59 age group has increased since April, it has continued to decrease for women in the same age group.

Marriage status in women acted as a further deterrent to employment rates. For example, 53.6 percent of married women were employed in June 2020 compared to 77.1 percent of unmarried women. Employment rates for the two groups have fallen 2.4 percent and 0.2 percent respectively year-on-year. Married and unmarried women tend to work in different industries, with married women holding disproportionately high numbers of jobs in accommodation and food and education services, two industries heavily impacted by COVID-19. In comparison, more unmarried women hold jobs in manufacturing and public health and welfare sectors, which have been less severely impacted. There are also indications that women are likely to experience difficulty in returning to the job market after having children 
and that when they do, they are less likely to return to jobs at previous skill levels.

\section{Women bear most of the burden of unpaid}

\section{work}

A survey of daily activities among the unemployed in South Korea during COVID-19 demonstrated that while men who were not working reported near zero hours spent on housework and childcare, women who were out of paid work reported spending the majority of their time on housework and childcare, vastly outweighing hours spent on leisure or preparation for future paid employment. Historically in South Korea, the trend has been that jobs held by women are the first to go in cyclical downturns, and women not in paid employment were inclined to settle into unpaid domestic work. Reflecting segregated gender roles, women absorbed most of the burden of caring for children when the start of the school year was deferred from early February to early June for students in most years. As a case in point, 64 percent of recipients of government subsidies for special carer's leave during the pandemic have been female.

\section{Government interventions in the jobs market}

The South Korean government has put in place several income and employment support programs ranging from employee retention subsidies for businesses and income support for eligible contractors and workers on forced leave. But COVID-19 has also highlighted gaps in the support system. Workers who are most impacted by the pandemic, such as low-income freelancers and those on "minimal hour contracts"-covering workers working less than fifteen hours in a month-are also least likely to be covered by the unemployment insurance scheme (UIS). Employers (and the self-employed) are required to contribute towards a worker's UIS for the duration of the worker's employment with them. However, compliance has been 
problematic among smaller employers who avoid paying into the scheme for nonregular workers. As of 2019, the UIS provided coverage for a mere 49.4 percent of all employed people including many self-employed who do not participate in the scheme. The limited effectiveness of the UIS is especially problematic in the South Korean context where the majority of self-employed are on low incomes and where the use of minimal hour contracts has doubled in the last ten years. A further barrier has been the absence of legislated sick leave in South Korea, the only member of the OECD besides the US not to offer statutory sick leave.

COVID-19 has also thrown a curve ball to the Moon Jae-In government's work and employment initiatives. The government's election promise to ensure all major public sector jobs are covered by permanent contracts, for example, has been less effectively implemented than hoped. The conversion of casual workers to ongoing contracts at Incheon international airport, a showcase workplace for this initiative, has faced opposition from contractors and the union representing permanent employees. Plans to expand the public provision of healthcare and increase residency seats in medical schools have been recently rescinded. These were derailed as they faced opposition from doctors and residents who mounted vigorous street protests in August 2020 in defense of their collective interests. Finally, at a time when dialogue between unions, business, and the government is needed to debate the country's economic future, the main umbrella group for trade unions, the Korea Confederation of Trade Unions (KCTU), has pulled out from negotiations over a demand for guaranteed protection for jobs.

Since successfully overcoming the public health challenge in the first wave of the virus's spread, South Korea has demonstrated an ability to periodically deal with ongoing large-scale outbreaks in May (79 cases new cases on $28^{\text {th }}$ May) and throughout August (441 new cases on $17^{\text {th }}$ August) and September, adjusting its policy with regards to social distancing as needed. As of $12^{\text {th }}$ October, the government has loosened restrictions in response to reductions in average daily cases from three digits to double digits, enabling karaokes and clubs to re-open. But 
COVID-19 is set to disrupt the structure of employment and employment relations in the country, providing at once a challenge and an opportunity to policy makers and social partners to re-think current structures for production and social protection. Ongoing policy discussions on a South Korean style "New Deal", referring to the post-war institutional response in the US to address the need to for fair distribution of prosperity and worker representation, suggest that this may be a pivotal moment in South Korea's employment history.

It remains to be seen whether these discussions will result in needed reforms that generate more equitable participation in the labour market as well as improved accessibility to social protection schemes such as the unemployment insurance scheme.

Image: Incheon Airport, March 2020. Credit: Jens-Olaf Walter/Flick

Quarantine, masks and dis/ease: social discourses of COVID-19 in Japan and Korea 